\title{
Meningkatkan keaktifan dan hasil belajar IPA siswa kelas VI SDN 02 Krompeng melalui pembelajaran Think - Pair - Share
}

\author{
Rini Hartatik \\ SD Negeri 02 Krompeng Kec.Talun Kab.Pekalongan
}

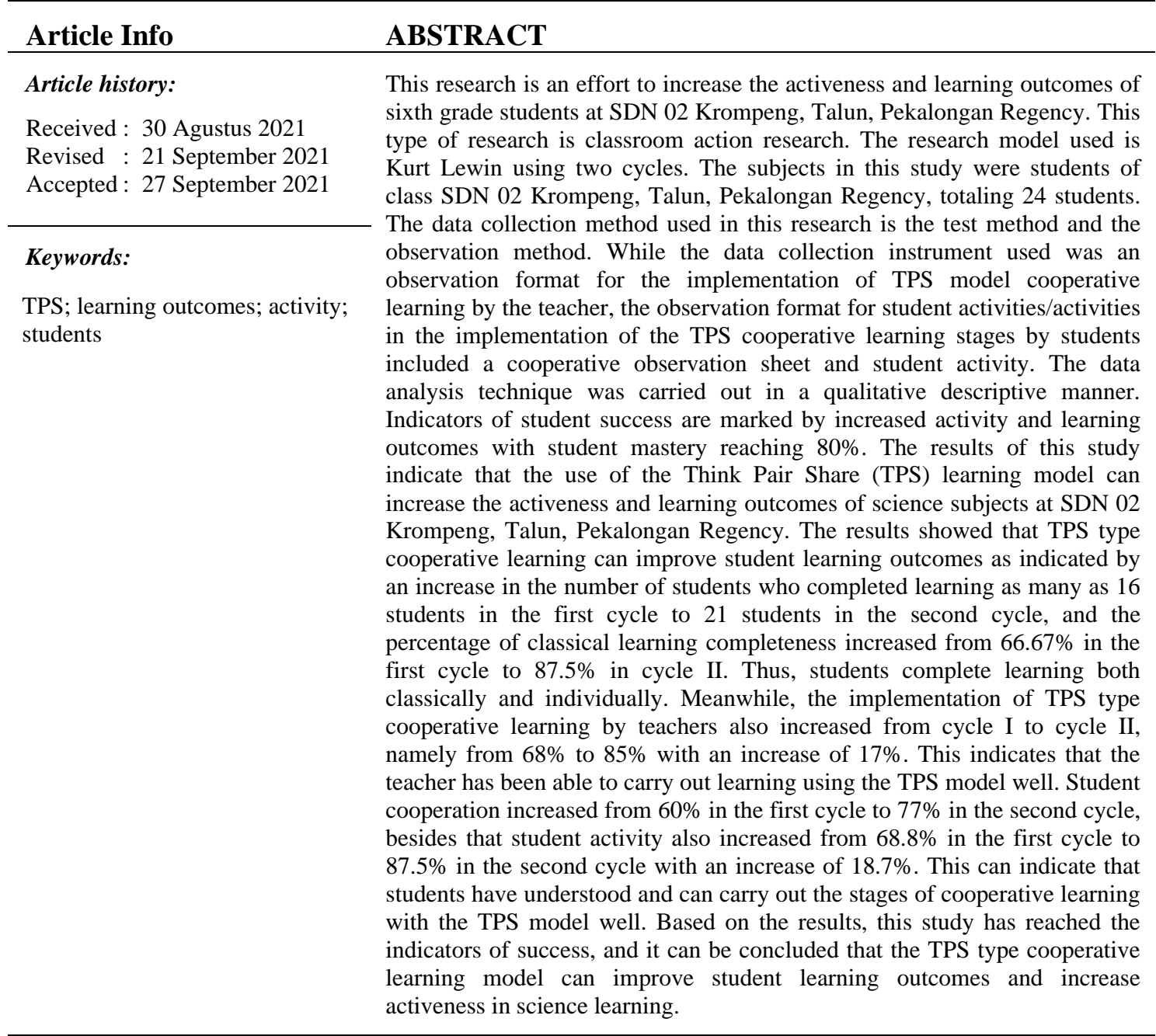

(*) Corresponding Author:

rinih.tatik@gmail.com

How to Cite: Hartatik R. (2021). Meningkatkan keaktifan dan hasil belajar IPA siswa kelas VI SDN 02 Krompeng melalui pembelajaran Think - Pair - Share. Action Research Journal, 1(1): 128-134.

\section{PENDAHULUAN}

IPA merupakan salah satu mata pelajaran yang diajarkan di sekolah dasar. Pendidikan IPA diarahkan untuk mencari tahu dan berbuat sehingga dapat membantu siswa untuk memperoleh pemahaman yang lebih tentang alam sekitar. Menurut Wahyudi (Gusti, 2014) pembelajaran IPA diharapkan dapat menjadi wahana bagi siswa untuk mempelajari diri sendiri dan harus mengantarkan siswa menguasai konsep-konsep IPA dan keterkaitannya untuk dapat 
memecahkan masalah dalam kehidupan sehari-hari yang sesuai dengan sikap IPA. Siswa diharapkan tidak hanya sekedar tahu, (knowing) dan hafal (memorizing) tentang konsep-konsep IPA, tetapi harus mengerti dan paham (to understand) terhadap konsep-konsep tersebut dan menghubungkan keterkaitan suatu konsep dengan konsep lain.

Pembelajaran IPA berjalan dengan baik apabila ada aktivitas siswa yang mendukung dalam pembelajaran, seperti aktif bertanya maupun mengemukakan pendapat (Nurjannah, 2019; Lasari, Zuhri, \& Widiyanto, 2021). Guru sebagai pembimbing juga berperan aktif dalam pembelajaran. Apabila siswa dan guru aktif maka diharapkan pembelajaran akan menjadi baik. Hal ini tidak sesuai dengan kenyataan yang ada dilapangan. Mata pelajaran IPA dianggap sebagai mata pelajaran yang sulit oleh sebagaian besar siswa sehingga keaktifan dan hasil belajar siswa rendah (Susanti \& Wijayanti, 2017; Lasari, Zuhri, \& Widiyanto, 2021). Pengalaman mengajar sebagai guru kelas menunjukkan bahwa keaktifan siswa kelas VI dalam pembelajaran masih kurang. Siswa cenderung pasif, siswa yang belum paham tentang materi yang diajarkan tetapi siswa hanya diam, dan takut untuk bertanya kepada guru. Akibatnya pencapaian keaktifan dan hasil belajar siswa yang rendah dengan nilai rata-rata 66 di bawah Kriteria Ketuntasan Minimal (KKM) yang ditetapkan yaitu 70. Siswa yang tidak memenuhi KKM ada 14 siswa sedangkan yang memenuhi KKM ada 10 siswa.

Di pihak lain rendahnya hasil belajar peserta didik disebabkan oleh proses belajar yang didominasi oleh pembelajaran tradisional (Lie, 2004). Pada pembelajaran ini suasana kelas cenderung 'teacher - centered' sehingga siswa menjadi pasif. Yang berakar dari paradigma guru yang memberikan pengetahuan dan siswa yang pasif, dan menganggap bahwa sudah merupakan tugas guru untuk mengajar dan menyodori siswa dengan muatan informasi dan pengetahuan (Rianingsih, Mawardi, \& Wardani, 2009; Permatasari, 2014). Guru perlu bersikap atau setidaknya dipandang oleh siswa sebagai yang maha tahu dan sumber informasi. Untuk itu, perlu adanya perubahan paradigma dalam menelaah poses belajar siswa dan interaksi antara siswa dan guru. Salah satu perubahan paradigma tersebut adalah orientasi pembelajaran yang semula berpusat pada guru (teacher centered) beralih berpusat pada murid (student centered), metodologi yang semula didominasi ekspositori berganti parsipatori (Trianto, 2007; Agusti et al., 2019). Selain itu, alur proses belajar tidak harus berasal dari guru menuju siswa. Siswa bisa juga saling mengajar dengan siswa lain (Lie, 2004). Semua perubahan tersebut dimaksudkan untuk memperbaiki mutu pendidikan baik dari segi proses maupun hasil pendidikan.

Salah satu model pembelajaran yang dapat menjadikan siswa aktif yaitu dengan menggunakan model pembelajaran kooperatif Think Pair Share (TPS). Model pembelajaran ini dirancang agar mengaktifkan siswa sehingga dapat meningkatkan keaktifan dan hasil belajar siswa (Trianto, 2007; Agustin et al., 2019). Model pembelajaran Think Pair Share atau berpikir, berpasangan, berbagai adalah jenis pembelajaran kooperatif yang dirancang untuk mempengaruhi pola interakasi siswa. Proses yang digunakan dalam TPS ini dapat membantu siswa lebih banyak berpikir untuk merespon dan saling membantu. Guru hanya menyajikan secara singkat atau siswa membaca tugas sekaligus kemudian mereka lebih banyak menjelaskan hal yang mereka pikirkan dan alami (Raditya, Kristiantari, \& Suara, 2015). Model pembelajaran ini tergolong tipe kooperatif dengan sintaks: guru menyajikan materi klasikal, berikan persolan kepada siswa dan siswa bekerja kelompok dengan cara berpasangan sebangku (Think Pair), presentasi kelompok (Share), kuis individual, buat skor perkembangan tiap siswa, umumkan hasil kuis dan berikan reward Meri (2018). Dengan model pembelajaran tersebut diharapkan dapat membantu siswa untuk mencapai hasil belajar yang maksimal dan mengembangkan hasil belajar siswa. Sehingga model pembelajaran kooperatif perlu dipakai lebih sering di sekolahsekolah, karena seiring dengan cara globalisasi untuk menyiapkan anak didik dengan ketrampilan baru untuk bisa ikut berpartisipasi dalam dunia yang berubah dan berkembang pesat (Sumarya, 2020).

Berdasarkan uraian tersebut di atas, maka rumusan masalah penelitian ini adalah Apakah Penerapan Model Pembelajaran Think Pair Share (TPS) dapat Meningkatkan Keaktifan 
dan Hasil Belajar Siswa Pada Mata Pelajaran IPA Kelas VI SDN 02 Krompeng, Talun Kabupaten Pekalongan?

\section{METODE}

Jenis ini adalah penelitian tindakan kelas (PTK). PTK adalah penelitian yang mengkombinasikan prosedur penelitian dengan tindakan substansif, suatu tindakan yang dilakukan dalam disiplin inkuiri atau usaha seseorang untuk memahami apa yang sedang terjadi, sambil terlibat dalam sebuah proses perbaikan dan perubahan. Dalam penelitian ini dilakukan dalam dua siklus, masing-masing siklus dengan tahapan perencanaan, pelaksanaan tindakan, pengamatan dan refleksi. Hubungan keempat komponen tersebut dipandang sebagai siklus yang dapat digambarkan pada Gambar 1.

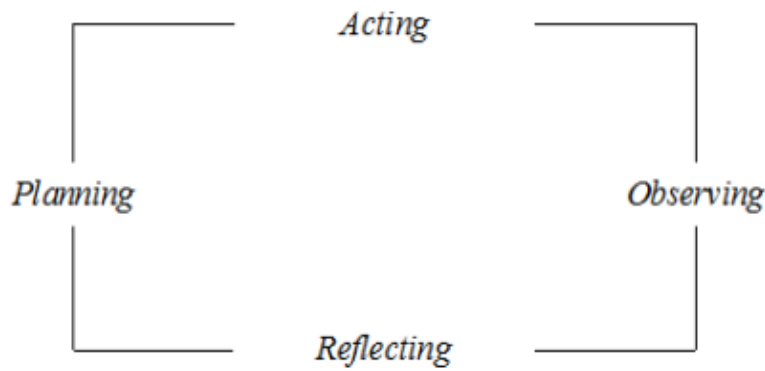

Gambar 1. Desain Penelitian Tindakan Kelas menurut Kurt Lewin

Dalam penelitian ini ada beberapa faktor (variabel) yang akan diteliti, antara lain: 1) Variabel siswa: dengan melihat kemampuan siswa dalam menyelesaikan soal, aktivitas siswa dan kerjasama dalam berpasangan, dan 2) variabel guru: melihat cara guru membuat rencana pembelajaran dan bagaimana pelaksanaannya di dalam kelas. Data dalam penelitian dikumpulkan melalui tes dan observasi. Kemampuan siswa dalam mengerjakan soal dan menyelesaikan masalah diperoleh dari hasil tes. Sedangkan kemampuan guru dalam pembelajaran, keaktifan dan kerjasama siswa diperoleh dari pengamatan selama pembelajaran. Data tentang kemampuan guru dalam pembelajaran, keaktifan dan kerjasama siswa dianalisis dengan menggunakan teknik deskriptif melalui persentase. Adapun rumus yang digunakan adalah:

$$
\text { Prosentase }(\%)=\frac{\text { jumlahskor yang diperoleh }}{\text { jumlah skor maksimal }} \times 100 \%
$$

(Arikunto, 2002)

Data mengenai hasil belajar diambil dari hasil siswa dalam memecahkan masalah dianalisis dengan menghitung rata-rata nilai-nilai dan ketuntasan belajar. Data ketuntasan belajar individual diperoleh dari kemampuan siswa menyelesaikan masalah dapat ditentukan ketuntasan belajar individu menggunakan analisis deskriptif persentase dengan perhitungan:

$$
\text { Prosentase }(\%)=\frac{\text { jumlah nilai yang diperoleh tiap siswa }}{\text { jumlah seluruh siswa }} \times 100 \%
$$

Data Ketuntasan belajar klasikal diperoleh dari kemampuan siswa menyelesaikan maslah dapat ditentukan ketuntasan belajar klasikal menggunkan analisis deskriptif persentase dengan perhitungan:

$$
\text { Prosentase }(\%)=\frac{\text { jumlah siswa yang tuntas belajar individu }}{\text { jumlah siswa }} \times 100 \%
$$

Indikator keberhasilan dalam penelitian ini adalah: 1) Kemampuan siswa dalam menyelesaikan masalah dengan nilai rata-rata kelas $\geq 70$, ketuntasan belajar individu mencapai $\geq 70 \%$, dan ketuntansan belajar klasikal $\geq 85 \%$. 2) Kinerja guru meningkat dalam pembelajaran menggunakan model kooperatif tipe think pair share dengan kriteria baik dan mencapai prosentase $\geq 75 \%, 3$ ) Keaktifan dan kerjasama siswa dalam mengikuti pembelajaran meningkat dengan kriteria tinggi dan mencapai prosentase $\geq 75 \%$. 


\section{HASIL DAN PEMBAHASAN}

Penelitian ini dilaksanakan dengan menggunakan metode penelitian tindakan kelas (PTK), dimana dalam penelitian ini ada dua siklus yang dilakukan untuk memperoleh data tentang keaktifan dan hasil belajar siswa kelas VI khususnya materi tematik IPA. Masingmasing siklus dilaksanakan dengan menggunakan model pembelajaran Think Pair Share (TPS). Pelaksanaan tindakan pada setiap siklus disertai dengan perencanaan, pelaksanaan, observasi, dan refleksi. Penjelasan dari tahapan tersebut pada masing-masing siklus sebagai berikut:

1. Perencanaan

a. Guru membuat rencana pembelajaran dengan model kooperatif tipe think-pair-share

b. Guru menyusun lembar observasi naik untuk siswa maupun untuk guru

c. Guru merancang pembentukan kelompok untuk menciptakan masyarakat belajar dan untuk menyelesaikan permasalahan

d. Guru menyusun alat evaluasi pada akhir siklus

2. Pelaksanaan Tindakan

a. Guru memotivasi siswa (memfokuskan perhatian siswa)

b. Guru mengkomunikasikan tujuan pembelajaran

c. Guru menjelaskan materi sesuai dengan rencana pembelajaran

d. Guru menyampaikan beberapa hal yang harus dilakukan siswa, misalnya: siswa diharapkan mengerjakan tugas secara kelompok berpasangan, kemudian mengungkapkan pendapat mereka dan mempresentasikan hasil diskusi

e. Guru membagi lembar kerja siswa kepada masing-masing siswa dan membimbing siswa mengerjakan secara mandiri (think)

f. Guru membimbing/mengarahkan siswa dalam berpasangan dan mendiskusikan apa yang telah mereka peroleh (pair)

g. Guru meminta pasangan-pasangan diskusi belajar dengan keseluruhan yang telah mereka bicarakan/diskusikan (share)

h. Guru membantu siswa membuat rangkuman diskusi dengan tanya jawab

i. Guru mengadakan evaluasi untuk mengetahui efektivitas belajar siswa

3. Pengamatan

a. Observer mengamati kegiatan guru selama proses pembelajaran dengan menggunakan lembar pengamatan sehingga semua kegiatan guru terekam secara optimal.

b. Observer mengamati kegiatan siswa yang meliputi sikap dan tingkah laku siswa selama proses pembelajaran meliputi keaktifan siswa dalam pembelajaran, pemahaman terhadap materi, dan kerjasama siswa dalam kelompok diskusi.

c. Peneliti melakukan penilaian terhadap latihan soal yang dikerjakan siswa

4. Refleksi

Data yang diperoleh dari hasil pengamatan selama berlangsungnya proses pembelajaran dianalisis dan dikaji keberhasilan dan kekurangannya dan hasilnya digunakan sebagai bahan penyusun rencana pada siklus berikutnya.

Hasil penelitian menunjukkan bahwa pembelajaran kooperatif tipe TPS dapat meningkatkan hasil belajar siswa dan kekatifan siswa. Keaktifan siswa selama proses belajar mengajar mengalami peningkatan dari siklus I yang hanya $68,8 \%$ menjadi $87,5 \%$ pada siklus II, walaupun masih ada yang siswa yang mengganggu siswa lain, tidak mendengarkan guru dan tidak mengerjakan tugas. Kerjasama siswa selama proses belajar mengajar juga mengalami peningkatan dari siklus I yang hanya $60 \%$ menjadi $77 \%$ pada siklus II, walau pada siklus I ada beberapa kelompok yang anggotanya tidak mau mempresentasikan hasil diskusinya. Hasil analisis evaluasi pada siklus I dengan rata-rata hasil nilai siswa secara klasikal 69,8 dengan ketuntasan belajar 66,67\% dan belum memenuhi indikator keberhasilan. Dari hasil analisis evaluasi siklus II masih ada 3 siswa belum tuntas belajar dengan nilai rata-rata secara klasikal 7,78 dengan ketuntasan belajar 87,5\% dengan rata-rata hasil nilai siswa secara klasikal 75,8 sehingga indikator keberhasilan tercapai. 
Pada siklus I guru sudah cukup mampu membagi waktu dalam melaksanakan kegiatan belajar mengajar. Kesiapan guru dalam pelaksanaan pendahuluan kegiatan belajar mengajar baik. Guru dalam membimbing siswa dalam kegiatan diskusi dan persentase hasilnya hanya mencapai 68\%, ini berarti bahwa guru mengajar dengan baik. Setelah diadakan perbaikan pada siklus II cara guru mengajar jauh lebih baik mencapai $85 \%$ dan lebih memahami pembelajaran kooperatif tipe Think-Pair-Share. Dengan demikian pembelajaran berjalan dengan sangat baik. Berdasarkan hasil penelitian setiap siklus secara keseluruhan pembelajaran kooperatif tipe TPS dapat meningkatkan hasil belajar siswa dikatakan berhasil. Berturut-turut dari siklus I dan siklus II terjadi peningkatan hasil belajar siswa, disajikan pada Tabel 1. Pada Tabel 1 diatas dapat dilihat bahwa semakin bertambahnya jumlah siswa yang tuntas belajar. Dan dari nilai siklus I ada 16 siswa yang tuntas belajar dan pada siklus II ada 21 siswa yang tuntas belajar. Dengan demikian karena lebih dari $85 \%$ siswa sudah tuntas belajar maka dapat dikatakan siswa sudah tuntas belajar secara individu maupun klasikal.

Tabel 1. Perbandingan Siklus I dan Siklus II

\begin{tabular}{|c|c|c|c|c|c|c|c|}
\hline No & Variabel & Pra Siklus & Ket & Siklus I & Ket & Siklus II & Ket \\
\hline 1. & $\begin{array}{l}\text { Keaktifan } \\
\text { siswa }\end{array}$ & $60 \%$ & $\begin{array}{l}\text { Belum } \\
\text { tercapai }\end{array}$ & $68,8 \%$ & $\begin{array}{l}\text { Belum } \\
\text { tercapai }\end{array}$ & $87,5 \%$ & tercapai \\
\hline 2 & $\begin{array}{l}\text { Kerjasama } \\
\text { siswa }\end{array}$ & $55 \%$ & $\begin{array}{l}\text { Belum } \\
\text { tercapai }\end{array}$ & $60 \%$ & $\begin{array}{l}\text { Belum } \\
\text { tercapai }\end{array}$ & $77 \%$ & tercapai \\
\hline 3. & $\begin{array}{l}\text { Rerata hasil } \\
\text { belajar }\end{array}$ & 66 & $\begin{array}{l}\text { Belum } \\
\text { tercapai }\end{array}$ & $68,8 \%$ & $\begin{array}{l}\text { Belum } \\
\text { tercapai }\end{array}$ & $75,8 \%$ & tercapai \\
\hline 4 & $\begin{array}{l}\text { Siswa } \\
\text { Tuntas }\end{array}$ & $62,5 \%$ & $\begin{array}{l}\text { Belum } \\
\text { tercapai }\end{array}$ & $66,67 \%$ & $\begin{array}{l}\text { Belum } \\
\text { tercapai }\end{array}$ & $87,5 \%$ & tercapai \\
\hline 5 & $\begin{array}{l}\text { Siswa tidak } \\
\text { Tuntas }\end{array}$ & $37,5 \%$ & $\begin{array}{l}\text { Belum } \\
\text { tercapai }\end{array}$ & $33,33 \%$ & $\begin{array}{l}\text { Belum } \\
\text { tercapai }\end{array}$ & $12,5 \%$ & tercapai \\
\hline 6. & Kinerja guru & $60 \%$ & $\begin{array}{l}\text { Belum } \\
\text { tercapai }\end{array}$ & $68 \%$ & $\begin{array}{l}\text { Belum } \\
\text { tercapai }\end{array}$ & $85 \%$ & tercapai \\
\hline
\end{tabular}

Pada siklus II mengalami peningkatan dari siklus I maka dapat dikatakan bahwa penelitian tindakan kelas ini sesuai dengan indikator keberhasilan sehingga hipotesis tindakan dapat dicapai berdasarkan refleksi tes siklus I dan tes siklus II . Dapat disimpulkan bahwa melalui penerapan model pembelajaran kooperatif tipe Think-Pair-Share dapat meningkatkan hasil belajar siswa, aktifitas dan kerjasama siswa juga meningkat. Hal ini disebabkan karena pembelajaran kooperatif tipe TPS mampu mengaktifkan siswa, mengutamakan kerjasama daripada model pembelajaran yang lain dan lebih mengembangkan kreatifitas serta pola pikir siswa.

Hasil penelitian ini juga didukung oleh penelitian yang dilakukan Santi \& Wijayanti (2017) yang menyatakan bahwa penggunaan model pembelajaran kooperatif tipe TPS berpengaruh terhadap hasil belajar IPA siswa ditinjau dari kerjasama siswa. Ini sejalan dengan penelitian Agustin et al., (2019) yang menjelaskan bahwa model pembelajaran Think Pair Share (TPS) berpengaruh positif terhadap hasil belajar IPA pada siswa. Kesimpulan serupa juga diungkapkan oleh Lasari, Zuhri, \& Widiyanto (2021) bahwa penerapan model pembelajaran kooperatif tipe think pair share mampu meningkatkan keaktifan dan hasil belajar siswa. Hal ini mengindikasi bahwa guru sudah dapat melaksanakan melaksanakan melaksanakan pembelajaran kooperatif tipe TPS dengan baik. Selain itu Ibrahim (Trianto 2007) mengatakan bahwa dalam pembelajaran dengan menggunakan model, memberikan peluang kepada siswa yang berbeda latar belakang dan kondisi untuk bekerja saling bergantung satu sama lain atau tugas-tugas bersama,dan melalui penggunaan struktur penghargaan kooperatif, belajar untuk menghargai satu sama lain. Trianto (2007) mengatakan bahwa bertujuan untuk memberikan kesempatan kepada semua siswa untuk dapat terlibat secara aktif dalam proses berpikir dan kegiatan belajar. Jadi ada aktifitas dan kerjasama dalam sebuah kelompok. Hal ini didukung pula oleh peningkatan aktivitas dalam proses pembelajaran, siswa lebih bermotivasi dan 
memiliki keberanian dalam mengungkapkan pendapat, pertanyaan dan koreksi, tumbuhnya sikap kritis, kolaboratif, demokratis dan inovatif dalam menyikapi persoalan yang dihadapi pada saat pembelajaran.

Dari Hasil penelitian menunjukkan bahwa pembelajaran kooperatif tipe TPS dapat meningkatkan hasil belajar siswa dan kekatifan siswa. Keaktifan siswa selama proses belajar mengajar mengalami peningkatan dari siklus I yang hanya $68,8 \%$ menjadi $87,5 \%$ pada siklus II, walaupun masih ada yang siswa yang mengganggu siswa lain, tidak mendengarkan guru dan tidak mengerjakan tugas. Kerjasama siswa selama proses belajar mengajar juga mengalami peningkatan dari siklus I yang hanya $60 \%$ menjadi $77 \%$ pada siklus II, walau pada siklus I ada beberapa kelompok yang anggotanya tidak mau mempresentasikan hasil diskusinya. Hasil analisis evaluasi pada siklus I dengan rata-rata hasil nilai siswa secara klasikal 69,8 dengan ketuntasan belajar 66,67\% dan belum memenuhi indikator keberhasilan. Dari hasil analisis evaluasi siklus II masih ada 3 siswa belum tuntas belajar dengan nilai rata-rata secara klasikal 7,78 dengan ketuntasan belajar 87,5\% dengan rata-rata hasil nilai siswa secara klasikal 75,8 sehingga indikator keberhasilan tercapai.

Pada siklus I guru sudah cukup mampu membagi waktu dalam melaksanakan kegiatan belajar mengajar. Kesiapan guru dalam pelaksanaan pendahuluan kegiatan belajar mengajar baik. Guru dalam membimbing siswa dalam kegiatan diskusi dan persentase hasilnya hanya mencapai $68 \%$, ini berarti bahwa guru mengajar dengan baik. Setelah diadakan perbaikan pada siklus II cara guru mengajar jauh lebih baik mencapai $85 \%$ dan lebih memahami pembelajaran kooperatif tipe Think-Pair-Share.

\section{PENUTUP}

Berdasarkan hasil penelitian maka dapat disimpulkan bahwa pembelajaran kooperatif tipe Think-Pair-Share dapat meningkatkan hasil belajar dan keaktifan. Hal ini ditunjukkan oleh bertambahnya jumlah siswa yang tuntas belajar, meningkatnya persentase kinerja guru dalam pembelajaran, meningkatnya jumlah kelompok yang melaksanakan kerjasama, dan meningkatknya keaktifan siswa dalam pembelajaran. Model pembelajaran kooperatif tipe Think-Pair-Share merupakan salah satu strategi pembelajaran yang sebaiknya diterapkan oleh guru karena dapat meningkatkan kemampuan siswa dalam memecahkan masalah selain itu suasana positif yang timbul dari model pembelajaran kooperatif tipe Think-Pair-Share bisa memberikan kesempatan pada siswa untuk mencintai

\section{DAFTAR PUSTAKA}

Agustin, N. K. T. J., Margunayasa, I. G., \& Kusmariyatni, N. N. (2019). Pengaruh Model Pembelajaran Tps Berbantuan Media Visual Terhadap Hasil Belajar IPA. Journal for Lesson and Learning Studies, 2(2), 239-249.

Arikunto, S. (2002). Dasar-dasar Evaluasi Pendidikan. Jakarta: Bumi Aksara

Gusti, I. A. T. A. (2014). Konsep Dasar IPA. Yogyakarta. Penerbit Ombak. Yogyakarta.

Lasari, V. N., Zuhri, A. F., \& Widiyanto, R. (2021). Penerapan Model Pembelajaran Think Pair Share Untuk Meningkatkan Keaktifan dan Hasil Belajar Siswa Kelas IV. Elementar: Jurnal Pendidikan Dasar, 1(1), 105-123.

Lie, A. (2004). Cooperative Learning. Jakarta: Grassindo.

Nurjannah, P. F. (2019). Pengaruh Model Pembelajaran Think Pair Share Terhadap Keaktifan dan Hasil Belajar IPA. Indonesian Journal of Educational Research and Review, 2(1).

Permatasari, S. (2014). Penerapan Model Pembelajaran Kooperatif Think Pair Share Untuk Meningkatkan Hasil Belajar IPA. Journal of Elementary Education, 3(1), 13-19.

Raditya, I. W., Kristiantari, M. R., \& Suara, I. M. (2015). Pengaruh model pembelajaran kooperatif tipe think pair share (TPS) terhadap hasil belajar IPA siswa kelas VI SD Gugus Letda Made Putra Kecamatan Denpasar Utara tahun ajaran 2014/2015. Mimbar PGSD Undiksha, 3(1). 
Rianingsih, D., Mawardi, M., \& Wardani, K. W. (2019). Penerapan Model Pembelajaran TPS (Think Pair Share) Dalam Rangka Meningkatkan Keterampilan Komunikasi Siswa Kelas 3. NATURALISTIC: Jurnal Kajian Penelitian Pendidikan dan Pembelajaran, 3(2), 339346.

Susanti, A., \& Wijayanti, A. (2017). Think Pair Share: Hasil Belajar IPA dan Kerjasama Siswa. Jurnal Pijar Mipa, 12(2), 51-59.

Sumarya, F. (2020). Meningkatkan hasil belajar peserta didik pada mata pelajaran IPA dengan metode Think Pair Share (TPS) pada siswa VIII A di SMPN 4 Tapung Hilir. Journal of Education and Teaching, 1(1), 37-49.

Trianto. (2007). Model-model Pembelajaran Inovatif Berorientasi Kontruktivistik. Jakarta: Prestaso Pustaka. 